\title{
Shopkeepers, Women, and Gendered Narratives
}

\author{
Gül Özsan
}

Department of Anthropology, Istanbul University, Turkey

Copyright $(2016$ by authors, all rights reserved. Authors agree that this article remains permanently open access under the terms of the Creative Commons Attribution License 4.0 International License.

\begin{abstract}
This paper examines how male shopkeepers (esnaf) construct narratives about women on the basis of the fieldwork conducted in the district of Moda, Istanbul between 2009 and 2013. While drawing attention to shopkeepers' significance in the discursive struggles over women, the essay aims to demonstrate that shopkeepers constitute one of the key social groups to be focused on for understanding narratives about women. I explore which types of narrative shopkeepers prefer to deploy, what references they make, and which ready-made narratives they disrupt. While placing these narratives within the context of everyday interactions between the two groups, this essay attempts to bring a fresh perspective on gender relations in the urban space. I argue that small shops represent a central site for the construction of social bonds between shopkeepers and women as members of a district community. Current forms of public discourse, hegemonic narratives, implied persons, various forms of gender ideologies, and the researcher herself are all deemed significant factors here. Moreover, processes of gender negotiations within everyday practices (including rapport-building activities) constitute the micro-politics of the construction and perpetuation of narratives. Shopkeepers' narratives about women shed light upon their perceptions of their own occupation, their relationships with the district community and various types of gendered subjectivities they form. The essay aims to demonstrate how the micro-politics of the co-production and reproduction of gender narratives functions by highlighting their embeddedness in everyday practices, in which both male shopkeepers and female residents interact and play an active role.
\end{abstract}

Keywords Shopkeepers (Esnaf), Occupations, Occupational Identities, Gender, Narrative and Narratives on Women

\section{Introduction}

This essay attempts to examine male shopkeepers' narratives about women, based on the research conducted in
Moda, Istanbul, between 2009 and 2013. The main aim is to explore the ways male shopkeepers construct narratives about women and to demonstrate how significant they are. More specifically, I will elaborate on which types of narratives shopkeepers choose to focus on while talking about women, which references they make, and how they construct their own narratives by employing or challenging ready-made ones. I argue that one of the main ways to find about gender narratives is to look into shopkeepers' narratives on women.

In order to attain a better understanding of these narratives, I look into the shopkeepers' business career stories and their perceptions of the district where they work. Their narratives on women are interrelated with these shopkeepers' positioning as subjects vis-à-vis their occupation, business and the district. The cases discussed below indicate that one of the focal points in the construction of the gender narratives is the ties they have with the district community and occupational identities. In other words, the narratives on women are embedded in those on the district and occupation. For this reason, the following questions constitute the background of this essay: What are the main constituent elements of narratives about women? What fundamental themes do occupational identities provide for the formation of gendered narratives? Are the conceptions of belonging to and representing a certain craft/vocation/occupation pivotal in the construction of gendered narratives? To what extent are shopkeepers aware of their central role in this respect?

While discussing the role of shopkeepers in the formation of narratives about women, I will focus on what kind of social relationships shopkeepers and women form. In other words, I maintain that the argument relating to the shopkeepers' crucial role in the construction of narratives about women becomes clearer in the context of everyday relations between the two groups. The strong social ties between shopkeepers and female district residents are most visible in the daily interaction in the small shops. The maintenance of everyday routine (the "normal" working of community life) is ensured through various social bonds formed and interactions carried out between shopkeepers and their customers. Small shops (esnaf dükkânlart), such as local hairdresser's salons (berber dükkânları), play a significant role in the construction of narratives on gender in 
general and on gender and community in particular. [2] Moreover, these are the sites where the social status of district residents (community members) is expressed, while a variety of nuanced community relationships are maintained. I claim that they are the heart of community life in a district. Thus, the main argument I put forward in this essay is that one of the significant-albeit overlooked-places where narratives about women are produced is small shops.

This argument makes it necessary to position narratives on women in a wide variety of broader contexts and debates in which they take on meaning. These narratives are usually products of the two parties (e.g. shopping women and male shopkeepers) and reproduced/re-enacted on a daily basis. Processes of gender negotiations within everyday practices (including rapport-building activities) form an important part of the micro-politics of the construction and perpetuation of narratives. Moreover, the answers to these questions may provide important clues about the formation of the image and collective memory of the district. In other words, images of shopkeepers, those of the district and gender images and narratives are constituted in interaction with each other, thus they have to be viewed as interrelated processes.[3,4,5] For this reason, it is important to look into the social positioning of shopkeepers within the district and strong ties women form with shopkeepers. More importantly for analyzing them, how and in what contexts are such narratives told? Current forms of public discourse, hegemonic narratives, implied persons, various forms of gender ideologies, and the researcher herself are all deemed significant factors here.

The research for this paper was conducted in one of the central districts in Istanbul, which distinguishes itself with a claim to be the zenith of modern and urban life. As a district, Moda (within the administrative unit of Caferağa Neighborhood, Kadıköy, on the Asian side of Istanbul) has a historical identity as a major site of Turkish modernization - an image whose repercussions are very much alive today. Most inhabitants of the district feel to be living in a "truly urban" part of Istanbul, which is often held to have lost its "authentic" urban identity due to its enormous expansion and increasing population (through rural migrants). Therefore, many people have the perception that shopkeepers (i.e. a group believed to be "traditional") do not occupy a crucial social position in this district. Taking an occupational group as the focal point of research, this essay attempts to bring a fresh perspective on the daily workings of modernity, urbanity and gender. For this reason, an ethnographic research based on long-term observations and in-depth interviews was conducted, aiming to make narratives on women visible with a focus on small shops and shopkeepers. As pointed out above, these narratives also reveal how they view their occupations and their ties with the district community and how they construct their own subjectivities. Thus, this essay aims to shed light upon the micro-politics of the formation and maintenance of gendered narratives within daily practices and in interaction with women.

\section{Moda: A "Modern" District in Istanbul}

The research for this essay was conducted in Caferağa Neighborhood, Kadıköy, Istanbul. As often pointed out in a large number of sources, this neighborhood is referred to as the district of Moda (Moda semti) in common parlance. Since semt (district) is not an administrative unit, the boundaries of Moda is often a topic of contention-an issue often raised in the interviews with detailed references to "core" places of the district. Compared with many other districts of Istanbul, Moda has long since been identified with the practices of "modern" life and consumption. Writings on the district underline the urban characteristics of its residents in sharp contrast to most people living in the other parts of the city. Moreover, we see discussions about the origins of the district's name. The loanword "Moda" borrowed from French (mode) in the $19^{\text {th }}$ century connotes the "Western" lifestyle in Istanbul as well as temporary style and fleeting trends. As far as the image of the district is concerned, the connotation of temporariness associated with the word loses its impact. On the contrary, "Moda" implies a lasting significance of the "modern" lifestyle. Another important characteristic that provides the district with prestige compared to some other similar districts of Istanbul (such as Etiler and Ulus) is that it was one of the first places of Western-style modernization in Istanbul and distinguishes itself with its long history of a particular lifestyle — at least in the collective memory. Therefore, the district image of Moda is in sharp contrast with the image of esnaf: the former represents modernity, whereas the latter is associated with traditionalism. Most people, including many scholars, who learned about my research expressed their surprise, they had difficulty in recognizing the very existence of esnaf in Moda. In fact, shopkeepers in Moda are not so visible, but they do constitute a powerful social group. They often underline that they are not only concerned with the quality and prices of their goods and services, and claim that they know the proper conduct with "prestigious" (nezih) ladies and gentlemen in the district, contrasting themselves with shopkeepers in the neighboring areas. Especially women of the district occupy an important place in this controversial issue.

One of the main determinants of the social positioning of shopkeepers within a district (semt) is the hierarchy of the districts on the map of the city mentally drawn by its resident. Another important factor that has to be taken into account here is the sense of belonging to the district. It is clear that the boundaries and status of districts cannot be explained solely by economic facts; rather, they are based on social struggles. Examining the social positioning of shopkeepers vis-à-vis district-dwellers and within the district may help us better understand what kind of adaptation, negotiation, and struggle strategies shopkeepers have developed. What is of particular relevance here is to think about their contribution 
to the construction of the memory of the district. Struggles about who "truly belongs" to a district or who "deserves" to live there are carried on through the various constructions of this memory. [3,4,5]

\section{Research Process and Method}

This essay rests on the in-depth interviews conducted, small talks held, and detailed observations made in small shops and in the district of Moda between 2009 and 2013. Since I lived in this district between 2008 and 2015 and have had an interest in this occupational group for long years, I had the opportunity to conduct the fieldwork in the district and small stores run by male and female shopkeepers and craftspeople. I took field notes about my observations regularly during this time period. I used a recorder in eight interviews with male shopkeepers, while I noted down their words in the other cases. Moreover, I carried out another field research on female shopkeepers in the same district between April and July 2015. In that study with a different focus and research questions, I conducted 38 in-depth interviews with women running small stores or craft workshops, thus gaining a broader and comparative perspective on the results of the research carried out between 2009 and 2013.

I tried to develop a fuller understanding of the community by engaging various techniques of ethnographic research. Small talks, chats, informal conversations (sohbet) and in-depth interviews provided me with the opportunity to look into the entire stories of small shops and the types of narratives shopkeepers tend to construct. Detailed observations in these shops and the district helped me to grasp how the "flow of information" on the district and its inhabitants works and how social bonds are formed. In fact, the observations made in the field were the key to understand the actual workings of narratives and community life. As a participant observer, I was able to figure out the significance of seemingly unimportant chats and gestures in the daily conduct of small shops, which turn out to be central sites for the construction of narratives about women. I observed how male and female shopkeepers construct a cultural and social world (a community) where they, their family members and acquaintances as well as district dwellers interact with each other while carrying out their daily routines and talking about their shops and business. Thus, small shops (especially ones run by women, but also those run by men) appear to be the sites of sociality where the public and the private tend to be blurred and entangled in narratives and "actual" conduct of daily life.

Finally, I did not include the branches of corporate "firms" or medium-size stores in my research. Many people interviewed in Moda viewed these stores as "temporary" places working with a completely different business ethos. Moreover, "semt esnafi" (district shopkeepers) are considered to be a distinct group as part of the community in everyday language, whereas other workplaces are held to be operated in a more formal way. In fact, the images and narratives about district shopkeepers are co-(re)produced by shopkeepers and district inhabitants in conjunction with the (re)production of the image of the district-these two processes of image production are inseparable from each other.

\section{The Common Image about Shopkeepers and Craftspeople}

What do we know about shopkeepers-craftspeople (esnaf-zanaatkârlar)? The common image, which seems to be reinforced by scholarly writings, can be summarized as follows: firstly, shopkeepers are viewed as an occupational/social group of the past, making a hopeless survival struggle within a world they do not belong to. There are several reasons for this perceived anachronism, but I believe that the hegemonic social scientific practice has been quite effective in the formation of this image. This perception of esnaf has been functional for the maintenance of hegemonic scholarly approaches, since it helps them to remain within the sharp divisions that they take pains to reproduce. In this essay, I will treat esnaf as a social category of the present, not of the past. Secondly, both our everyday image and the bulk of the relevant resources highlight small shopkeepers in particular locations such as Grand Bazaar (Kapalıçarşı) and old Istanbul. Most of the relevant illustrated books present a "touristic" picture centering on shopkeepers in certain historical districts in Istanbul.[6,7] This presentation too reinforces the common image of shopkeepers as an essentially anachronistic social group. Most studies on shopkeepers and craftspeople view them as the indicator of the continuity with the late Ottoman Empire. $[8,9,10,11,12,13,14,15]$ Many of them focus on the harmony and order amongst esnaf, leaving struggles and controversies within this group in the back ground.[16,17,18] As Faroqhi points out, most of the studies on Ottoman guilds, especially earlier pieces of research, focus upon their moral values and rituals rather than daily practical problems of handicraft production. For example, Gölpınarlı's and Melikoff's works deal with religious values and rituals, and this leads to a certain limited vision.[17,19] The number of the studies on the shopkeepers and craftspeople of the Republican era is far much less than the studies on those of the Ottoman period.[17] In fact, it will not be an exaggeration to claim that almost all the relevant writings in this field are on Ottoman shopkeepers and craftspeople. Moreover, most of these writings are about those in Istanbul.[20] Apparently, shopkeepers and craftspeople of Turkey have been a focus of interest mostly for historians rather than sociologists and anthropologists.[17]

An important question in this context is how women figure in scholarly work on shopkeepers and their common everyday images. The bulk of the literature presents us with a men's world when they speak of esnaf. We can see, however, a large number of women specialized in specific 
areas even in the Ottoman past if we examine sources and illustrations carefully. Moreover, it is possible to find about the relationships between women of various classes and esnaf in Istanbul, especially the controversies over certain issues. We also learn about the presence of female shopkeepers outside Istanbul too. [7,16,17,21] Thus, the historical research provides us important clues about the issues relevant to this paper, especially demonstrating that social relationships between women and esnaf constitute a noteworthy aspect of Ottoman urban life and its daily routines. We also learn that women worked not only in the textile industry, but in a wide variety of areas as esnaf and craftspeople. We can draw parallels between these observations about the Ottoman past and contemporary Istanbul. In addition, we know that a large number of small shops or workshops are family businesses in which women play an active part in it. [3,4,5]

The common image about shopkeepers in Turkey is that they are all male. Definitions about esnaf (shopkeepers) and zanaatkâr (craftspeople) assume that holders of these occupations are male, thus tending to reinforce their gendered nature. [12,22] Perhaps this has something to do with the idea of public sphere and guilds in the Ottoman Empire, the administrative organization still maintained and developed in the Republican era, and the gendered images and cultural codes of mahalle (the smallest administrative unit in an urban area in both the Ottoman and Republican times) ${ }^{1}$. Thus, mahalle appears to incorporate well-defined and gendered social relationships organized by public (masculine) power. Everyday expressions, words, and metaphors about mahalle reflect this image of an orderly world whose public domain is controlled by men. "Craftsmen" and esnaf seem to be the guardians of this public order and masculinity in the urban space. Today, the wide range of nuanced behaviors of shopkeepers in a certain district (mahalle esnafi) towards women are related to all these images - especially the differences in their treatment of poor (or single) women and well-to-do (or married) women are meaningful in this respect.

Most studies on neighborhoods in Turkey have been made by scholars in the fields of architecture, urban planning, and urban studies. In their writings, the neighborhood appears to represent the traditional social structure organized around communal relationships. Therefore, changes occurring in neighborhoods have been viewed as the loss of social support networks and the decline of the sense of community.[23,24,25,26] Hence, the abovementioned perception of esnaf as essentially a group of the past representing traditional relationships is relevant for the mahalle too. Many sociological and anthropological writings seem to reproduce this perception, taking the dichotomy of tradition and modernity as their point of departure. This schematic and reductionist perspective does not contribute to understanding complex relationships of a neighborhood/district community and the social dynamics of continuity and change. Moreover, it is an obstacle to gaining insight into the wide variety of struggles over "the past" and "tradition" strategically waged by neighborhood/district residents and shopkeepers.

\section{Social Relationships between Shopkeepers and Women}

As stated above, Moda differentiates itself from other districts of Istanbul with a large and very active group of female and male shopkeepers and craftspeople, who are not very visible at first sight. For male shopkeepers and craftsmen, like their female counterparts, the location of their shops is of vital importance in their struggles for social distinction. More importantly, they build and maintain a wide variety of social relationships on different levels within the community and outside while starting their business and thereafter. A major theme in shopkeepers' narratives is the way they have carried on their business thanks to these relationships. As they often express, the challenge is not about opening a small shop, but about acquiring and maintaining a solid place within the community and business life (which seem to be not very separable). Before discussing the interviews in detail, I would like to focus how and with whom they form social ties which they consider to be crucial.

I maintain that two points are important in this respect. First of all, like their female counterparts, most male shopkeepers state that they were able to open their shops by mobilizing the support of and maintaining a delicate balance with their family (often involving ties larger than those of the nuclear family). Furthermore, they point out that their shops have been able to carry on their existence thanks to a large network of social support and relationships, while some were launched and have been run as family businesses. According to their accounts, particularly in the initial phase of the business, various forms of capital that their family provides were of critical importance for them. They underline the necessity for having a certain level of economic and social capital at the outset. Finding a "proper" shop, gathering the initial financial capital, obtaining the necessary goods/materials, and running the relationships with the municipal authorities smoothly all depend on a certain social power base stemming from family, acquaintance and community ties. Moreover, they were able to develop various social skills while running their business by utilizing the resources and skills they had already acquired within their family life. In fact, they have been able to become "the district's shopkeepers" by forming intricate relationships with well-established shopkeepers and prestigious individuals and families in the community. They believe that this is the key for maintaining their shops. In short, it is held that some shopkeepers become more advantageous thanks to the various forms of capital provided by their family, their utilization of family resources, and the 
skillful use of social networks. Unsurprisingly, the shopkeepers interviewed mention or allude to a number of tensions and arguments during all these processes. For example, family members sometimes had disagreements or disputes over to whom family resources be transferred or how the division of labor within the family be planned. Moreover, the changes in the local or national political life might become threatening to their business life.

As for the second point concerning social ties shopkeepers form and maintain, we should be attentive to differences amongst shopkeepers in a district. All shopkeepers point to the significance of "small talks" or chats they have with community members and fellow shopkeepers. Indeed, they feel this is the basic art that they have to skilled at in becoming a "well-established" shopkeeper as well as finding venues to maintain social ties on various levels. An interesting point observed is that relatively new shopkeepers have the same claim to be already "well-established" and they advance their claim even more forcefully than the others. In fact, none of the former fails to underscore the significance of developing community ties and understanding the social fabric of the district. Thus, the claim to be a "well-established" shopkeeper is not framed with the "objective" period of time they have spent in the district. Regardless of the time period they have run their business there, they find it important to be viewed as "the district's shopkeepers" and to identify themselves with Moda. As will be discussed below, they express their preference for the prestigious social life there. Therefore, I argue that this is an important segment of shopkeepers who are particularly vocal in producing and reproducing the main narratives about belonging to Moda and its "culture" (Modalılık, Moda kültürü).

On the whole, we can say that whatever their differences are, all shopkeepers lend significance to the status of the district and its inhabitants, thus trying to raise their own status. The importance they attribute to their social ties with the community becomes more intelligible in this context. In other words, shopkeepers strive to form strong ties with the prestigious district and its "prestigious" inhabitants and construct narratives about them, and by doing so, they attempt to distinguish themselves as more prestigious. It is clear that the image of "well-established district" (köklü semt) and that of "well-established shopkeepers" (köklü esnaf) reinforce each other. The main question here is what segments of the shopkeepers in the district are more successful in this respect and what methods and forms of capital they use for this purpose. I argue that those who strive most to make use of the symbolic capital provided by the district are those with relatively limited economic power and less cultural capital. Members of this group tend to capitalize upon the status of the district, by embracing a very strong narrative about its "culture" ("Moda culture")—-waging a struggle for recognition as guardians of this "culture". They seem to be very keen on this point - always enthusiastic about impressing the researcher with their "theory of culture" and showcasing their "insider's" knowledge about the uniqueness of the district. Perhaps, they feel that they need their positioning in the status struggle much more than others in order to survive economically. More importantly for this article, they are more motivated about constructing narratives on women, trying to demonstrate they are "truly modern" and "urban" vis-à-vis gender issues. Their sensitivity about women is very much related with their conception of Moda as the symbol of modern urban life. In short, the social relationships Moda shopkeepers form with women and the narratives they construct should be read with an eye to this social and cultural backdrop.

We can observe that shopkeepers in Moda have formed the ties with women and powerful families in order to build up various types of capital; shopkeepers' claims of cultural capital are particularly significant in this respect. They struggle to maintain the prestigious status of the district, presenting themselves as both constituting and symbolizing this status. In addition, we also encounter controversies over various issues, such as the construction of shopping malls and their problems with the owners of workshops or craftspeople. A large number of shopkeepers try to increase their economic power by taking positions in various non-economic issues, striving to convert non-economic types of capital into economic capital. Male shopkeepers' position taking in various issues tend to Women appear to be a focal point of reference in political and cultural debates in Turkey. Even the smallest details of women's conduct are objects of attention (sometimes even sources of heated debates), and men's position-takings vis-à-vis women's place in the social life are taken to be the indicators of political and cultural worldviews or signals for a various types of lifestyle.

When we look into the relationships between shopkeepers and women living in a certain district, we see that they base their conduct upon a series of tacit agreements. I would like to underline the significance of their relations, which, undoubtedly, display great variety. Women in Moda are certainly aware of the significance of their relations with shopkeepers. In my shorter or longer conversations with quite a few people in the district, I have often observed how women and shopkeepers form a space of social relations. I refer to a field of social knowledge based on controversies of gender and economy over who deserves to live where, hence urban identity. What I find striking amongst a lot of characteristics defining shopkeepers is that they represent a "balancing" factor in the district. Here we come across with a space of negotiation and compromise as well as a number of opinions about women. Shopkeepers take both certain stances and unifying roles. Strong social ties between shopkeepers and women in the district are made up of various positions co-determined by them. I believe that this corresponds to a social field, involving a social language and type of knowledge. Thus, it is impossible to speak solely of the pressure or liberating effects of shopkeepers in gender issues. In short, the positions and position-takings of women and shopkeepers in the district should be examined very carefully. In order to provide a solid base for what I have 
said thus far, I would try to illustrate my points with example cases.

"First, let us correct that: women understand these things better than men"

Having created some time amongst her busy schedule, a woman entered one of the old stores in Kadıköy selling electrical apparatuses and telephones. This small store is crowded even during daytime. It is usually men who visit this kind of stores, and that was the case that day too. The shopkeeper, who is a self-confident old man, gives "good" advice to, even "warns" almost everybody about buying the "correct" goods, meaning those things that are practical and affordable. He represents to many the wisdom of an experienced shopkeeper. When the woman reached out to a black receiver, he warned her: "but that is too expensive! You should buy the white phone for your home!" While he had to deal with so many people and things at the store, he explained the reasons to her and all the men there. It was not appropriate for a "true" shopkeeper to allow a customer to buy something impulsively - a customer should consider the matter carefully, not in a haphazard fashion. When she took the white, quite cheap phone in her hands, thinking of the restricted time she had, and forgetting all the warnings about the proper conduct at the store, she said: "I can't install the line; you know women don't understand these things." Both statements were easy for her to say, she probably thought by herself: "I said what I wanted. I am sure he understands what I mean. Maybe he can recommend a practical solution. Or he can make the process easy by affixing something to the receiver. Maybe he can come home..." While all these quick ideas were about to disappear, the shopkeeper said to her and the men around with a louder and self-confident voice: "First, let us correct that: women understand these things better than men." By making reference to misogynistic views on women expressed by some male members of the government party, he added: "they tell such things about you, but it is true neither for you nor for the other women." In his opinion, the women he met at that store were skillful and had achieved so many things; therefore, there was no need for further proof of women's capabilities. He was happy to point to Turkish women's accomplishments since the proclamation of the Republic. That is how the current ideological debates determine everyday discourse! Like all the other narratives, those about women can only be constructed within a certain historical and cultural moment. Speaking to the current hegemonic political discourse, heated public debates about lifestyle and emotionally charged position-takings make themselves apparent in this case. Moreover, this is how narratives are co-produced in daily practices by different actors such as the shopkeeper and male and female customers at the store.

The second person whose interview I will discuss now is another shopkeeper who had run a store in another old district of Istanbul for a long time. In fact, he was proud of his long career in business. He said that he had always dreamed of operating a shop in Moda. At the time of the interview, his son had taken over the daily operation of the business and he was present in the shop less often. His son looked very much in line with his father. At the beginning of the interview, the father said that he was in charge of the general decisions about the business. His son performed the daily tasks, but he seemed to accept his father's role and position as the true operator.

The main distinguishing characteristic of this shopkeeper (the father) was the outward signs of religious capital he possessed and his self-positioning as an old, experienced person in business by foregrounding the sophistication and quality of products he sold in the shop and putting the importance of Moda in the second place. They were not very enthusiastic about the "culture of the district," even though they pointed to its prestige. The center of their narrative was not Moda, but their shop and customers- "distinguished, cultured ladies and gentlemen". They meant not only those customers visiting their shop in Moda, but those visiting their former shops. Thus, they positioned themselves as the "old, distinguished shopkeepers of old districts", highlighting their own economic and social capital.

"Ladies and gentlemen used to come here."

The apartment I moved to in August 2009 is considered not to be in Moda, but closer to Mühürdar (a less prestigious quarter). It represents all the social and spatial features of being in the border area and the object of this kind of debates. The struggles between the workshops of craftspeople and the "arts" workshops such as painting and ceramics are easy to observe in the street. There is an antique dealer's store called "Eski Moda" ("Old Fashion") at the beginning of the street. Down the street there is a tailor's store that sells second-hand dresses and provides sartorial services such as mending, renewing, and modifying old clothes. One cannot but notice the hustle and bustle in this not-so-long street. One of the eye-catching workplaces in the street is the store that sells dairy products. The shopkeeper runs the business together with his son. In our chats, he speaks mostly about Moda, people living here, and his customers. He tells me that when he lived in another district in Istanbul, he dreamt of moving here. In his stories of "good old days," customers were all "ladies and gentlemen" who truly belonged to this fancy district. He is keen on describing them in detail by giving examples. Even though some changes have occurred in recent years, he believes that most customers today can be considered to be almost like earlier ones too. Moreover, he claims that some people are able to improve their conduct by visiting his store. In his opinion, his own conduct influences especially the younger generation.

The abovementioned two men construct their narratives with reference to a historical background (and the political conjuncture) and other grand narratives about gender and the district. This background also helps us to make sense of their words. In fact, shopkeepers (just as female customers) tend to use ready-made narratives of life that are currently in circulation. The key role of shopkeepers becomes apparent in their handling of the social knowledge, language, and micro-politics as well as women in the district.

As pointed out above, another important point for the 
researcher here is to recognize the significance of the narratives of the occupational identity. Narratives about a certain occupation usually provide a solid basis for narratives about gender. I have observed this point in the narratives of male hairdressers,[2] grocers, and plumbers. In fact, these narratives of occupation are powerful since they are based upon other gendered narratives, especially those about female customers. When both types of narratives (i.e. those about occupation and gender) are deployed in an interrelated manner, they are able to maintain, reproduce, and modify other cultural codes. This is what I meant by the micro-politics of the construction of narratives. In short, narratives about occupations and those about gender seem to interpenetrate into each other, thus it is necessary to analyze them as inseparable. Gender narratives are crucial for both women and male shopkeepers in their everyday practices.

The third interview I would like to discuss was held with a greengrocer with a very modest background. In the early 1970s, when he was eight, his family moved to Moda from Sivas, a Central Anatolian town. The quarter they moved to is called the "Moda Point", the peninsula at the district. Most people regard this quarter as the "truly distinguished" part of the district and consider it to be "real Moda". He began his working life as an apprentice at a grocer's. After some time, his father started to work as a travelling tradesman selling fruit and vegetables - first on a wheelbarrow, then on a pick-up truck. He helped his father in this job. After that, he rented a greengrocer's store at the Moda Point, where, as he emphasized, he was able to develop his business and network of acquaintances. He identified himself with Moda, which occupies a central place in his life story and career narrative. Finally, in the late 1980s, he bought the greengrocer's store, where I conducted the interview. The store is not on border zone with what he viewed as "Moda" and he takes pains to underline that the location is "not Moda, but Mühürdar". But he hastens to remind me of the fact that he spent most of his life in Moda. In his view, living in Moda (or nearby) presents unique opportunities for embracing a refined lifestyle and developing oneself. He points out that he has been able to find a great many people there with whom he could talk on a variety of things and could have a common "civilized language". He argues that the people living there are able to lead a "good social life", which he believes his family is not able to entirely share. In his opinion, the greatest hindrance to embracing this lifestyle is his occupation. Even though he can earn his and his family's living as a greengrocer, he is not happy with this job. His dream is to be a fixer working for a large firm, "who develops himself all the time." In fact, he has a second job as a repairman and mends his customers' and their children's bicycles in summer days. During the two long interviews I held with him and at other times, I observed that he was quite skillful in the repair job. He has a very friendly nature, enjoying talks with a large number of people from all walks of life in the district. In his view, what distinguishes Moda is the "elegant ladies and gentlemen" living there, thus his relationships with them are very important for him. In this respect, he places himself in a central position in the district. Moreover, in his narrative, Moda appears to be a gendered place, displaying feminine characteristics. He also emphasizes that this is a well-established and cosmopolitan district. He has a detailed knowledge about his customers' food preferences. For example, he is able to talk for a long time about the fruit preferences of the few Greek ladies living there.

\section{6. "We know the culture of Moda"}

The greengrocer has been running his shop for the last 15 years at a juncture point where two very different streets intersect. Even though several luxury greengrocer shops opened in nearby locations during these years, most of them had to close down in a very short space of time. A friend of mine told me that the secret of his success was not in his goods (he has never had much variety unlike other greengrocers), but in the type of relationships he has been able to maintain with people in the district over the years. In our interview, he starts to talk saying " $W e$ know the culture of Moda." He says that he has known the district since his childhood, and that he has been "a child of Moda." He tells in detail about the district and its social relationships in detail. According to him, it is very important to know each other here. "This is a culture of refinement: the culture of men and women whose conduct is refined. That is how Moda is..." He seems to claim that this is the prerequisite of being a shopkeeper in Moda. His language is that of a community heavily loaded with class distinctions. For him, being a resident in Moda implies a status marker. He knows a lot of people in the district-especially women. I had to describe to him very well where I lived. He is really helpful. When women have parking problems, he parks their cars. Some women leave him their apartment keys so that their children can pick them up when they return from school. He is keenly aware of the factors that make him powerful in the district, seizing the opportunity to compare himself with the nearby supermarkets. In his opinion, the main difference lies in the knowledge about the district (and the people) and "having acquired the manners of the district."

\section{Conclusions}

In this paper, I have tried to show how male shopkeepers construct narratives about women on the basis of the observations made and the interviews conducted in Moda, Kadıköy between 2009 and 2013. I have positioned the shopkeepers' role in the construction of narratives about women within the framework of social relationships. The cases discussed above clearly indicate the significance of social and political backdrop for understanding gender narratives. Moreover, small shops appear to be central sites for the construction of community relationships, where the commonly-held distinctions between the public and the 
private are constantly challenged. These shops are also the places where labels of masculine and feminine are not easily applied, hence the need for rethinking the gendered nature of urban public spaces.

I argue that narratives are co-produced within everyday practices by shopkeepers and female customers. Shopkeepers' narratives reflect the connections between the district identity and gender discourses. Debates about who are "true" residents of Moda and who deserves to live there represent the struggles over narratives about men and women and their "proper" conduct. Efforts to strike a delicate balance in gender relations appear to be the key for maintaining community ties; therefore, gender narratives must be viewed within this framework.

\section{Notes}

1.This study was first presented in the international symposium "Writing Women's Lives: Auto/Biography, Life Narratives, Myths and Historiography" organized by the Women's Library and Information Center Foundation and the Department of History, Yeditepe University in Istanbul on April 19th-20th, 2014. A selection of the papers presented in this symposium was published in the book form: Birsen Talay Keşoğlu \& Leyla Şimşek-Rathke, eds. Writing Women's Lives: Auto/Biography, Life Narratives, Myths and Historiography International Symposium Paper Book, Kadın Eserleri Kütüphanesi ve Bilgi Merkezi Vakfi, Istanbul, 2016. This article is a revised version of the chapter in that book. [1]

2. Mahalle is variously translated into English as district, quarter, ward, or neighborhood. I opted for "neighborhood," reserving the word "district" for semt.

3. Grocers and greengrocers closely follow the changes in shopping practices and try to take advantage of them. They take pains to represent themselves as those who maintain the "mahalle culture." In her research on Fikirtepe, Kadıköy, Istanbul, Neslihan Akpınar held an in-depth interview with a grocer (January 11, 2012) and observed the significance of his use of the term "the culture of mahalle shopkeepers" (“mahalle esnafllğı kültürü̈).

\section{REFERENCES}

[1] Özsan G. Shopkeepers, women, and gendered narratives. In Talay Keşoğlu B, Şimşek-Rathke L, editors. Writing women's lives: auto/biography, life narratives, myths and historiography international symposium paper book [Internet]. İstanbul: Women's Library and Information Center Foundation;2016. 308-314p. Available from: http://kadineserleri.org/.../sem.../sempozyum_bildiri_kitabi. pdf. ISBN: 978-975-92378-1-3.

[2] Özsan G. Two Barbers in beyoğlu: two types of narrative and two forms of masculinity. Toplum ve Bilim. 2010; 117: 86-118.
[3] Özsan G. Esnaf-zanaatkârlar, semt ve kent. In: Onaran İncirlioğlu E, Kılıçbay B, editors. Mekân ve kültür. İstanbul: Tetragon Yayınlar1; 2011. 99-107p.

[4] Özsan G. Moda merchants' adaptation and coping strategies for today's economic and social conditions: an assessment on using etnographic method in the research. İstanbul:Paper presented at the european conference on social science research (IASSR); June 2013.

[5] Özsan, G. Moda'nın semt imgesinin ve belleğinin oluşumunda esnafin rolü. Ankara:Paper presented at the 7th International Cultural Studies Symposium; September 2013.

[6] Sakaoğlu N, Akbayar N. Osmanlı'da zenaatten sanata: esnaf ve zenaatkârlar.İstanbul:Körfezbank;1999.

[7] Ișın E. 19. yy'da modernleşme ve gündelik hayat. İstanbul: İletişim Yayınları Tanzimat'tan Cumhuriyet'e Türkiye Ansiklopedisi; 1985.27p.

[8] Ergin ON. Türkiye'de şehirciliğin tarihi inkişafi. İstanbul: İÜ Hukuk Fakültesi İktisat ve İçtimaiyat Enstitüsü Yayını; 1936 [1922].

[9] Genç M. Osmanli esnafi ve devletle ilişkileri. Ahilik ve Esnaf Konferanslar ve Seminer. İstanbul: İstanbul Esnaf ve Sanatkârlar Dernekleri Birliği Yayını;1986. 113-124p.

[10] Genç M. Osmanli imparatorluğu'nda devlet ve ekonomi. Ankara: Ötüken Yayınları; 2000.

[11] Kafadar C. Yeniçeri -esnaf relations: solidarity and conflict. PhD diss., McGill University;1981.

[12] Kal'a A. Esnaf. İstanbul: Diyanet İşleri Başkanlığı İslam Ansiklopedisi;1994.8p.

[13] Kal'a A. Osmanli esnafi ve sanayisi üzerine yapilan çalişmalarla ilgili genel bir değerlendirme. Türkiye Araştırmaları Literatür Dergisi. 2003; 1(1): 245-265.

[14] Kazıcı Z. Osmanli devleti'nde toplum yapısı. İstanbul: Bilge Yayınlar1;2003.

[15] Koçu RE. Tarihte istanbul esnafi. İstanbul: Doğan Kitapçılık;2002.

[16] Faroqhi S. Osmanli kültürü ve gündelik yaşam. İstanbul:Tarih Vakfi Yurt Yayınları;1997.

[17] Faroqhi S, Randi D. Preface. Understanding Ottoman Guilds.In: Faroqhi S, Randi D, editors. Crafts and craftsmen of the middle east. London - New York: I.B. Tauris;2005.iv-vp.3-40p.

[18] Yıldırım, O. Osmanlı esnafinda uyum ve dönüşüm: 1650-1826. Toplum ve Bilim.1999/2000; 83: 146-175.

[19] Gölpınarlı A. İslâm ve Türk illerinde fütüvvet teşkilâti ve kaynaklari. ÏÜ İktisat Fakültesi Mecmuasi. 1949-1950;11(1-4): 3-354.

[20] Cumhuriyetin 50. yılında esnaf ve sanatkâr. Ankara: Güneş Matbaacilik;1973.

[21] Toprak Z. Esnaf. İstanbul:Tarih Vakfi Yurt Yayınları Dünden Bugüne İstanbul Ansiklopedisi; 1994.

[22] Hatemi H. Tanzimat ve meşrutiyet dönemlerinde derneklerin gelişimi. İstanbul: İletişim Yayınları Tanzimat'tan Cumhuriyet'e Türkiye Ansiklopedisi;1985. 6p. 
[23] Mills A. Streets of memory: the kuzguncuk mahalle in cultural practice and imagination. PhD diss., The University of Texas at Austin; 2004.

[24] Mills, Amy. Streets of memory: landscape, tolerance, and national identity in istanbul. Athens, GA: University of Georgia Press, 2010.
[25] Bayartan M. Osmanli şehirlerinde bir idari birim: mahalle. İÜ Coğrafya Dergisi. 2005;13: 93-107.

[26] Erkip F. Community and neighborhood relations in Ankara: an urban-suburban contrast. Cities 27. 2010: 96-102. 